\title{
Enterprise Cost Management and Analysis Based on Lean Accounting System
}

\author{
Wen Li \\ Guangzhou Vocational College of Technology \& Business, Guangzhou, China, 511442
}

Keywords: Accounting system; enterprise; cost management

Abstract: At present, China's economy has changed from high-speed growth stage to high-quality development stage. Enterprises and managers of enterprises have realized the need for lean operation to improve their own efficiency. In the new era, high-quality accounting services are needed to promote high-quality economic development. Under this background, the enterprise cost management model of accounting system has attracted the attention of business managers. Starting from the concept of enterprise cost management in accounting system, this paper discusses the current situation of the existing problems in enterprise cost management methods, and further discusses the specific measures of enterprise cost management in accounting system, hoping to provide new reference for the research and analysis of enterprise cost management based on accounting system, so as to promote the steady and healthy development of enterprises in China.

The ultimate goal of cost management in enterprises is to effectively reduce the cost consumption in their daily operation and management activities, and ultimately to maximize their operating profits. In fact, the standard cost method is the dominant accounting system in most enterprises in China. This accounting method easily leads to the disconnection between the daily operation and management activities of enterprises and cost management. In order to get rid of this problem, the managers of enterprises should adjust the original cost management methods, introduce lean accounting system, and reduce the consumption of useless costs. Effectively control the cost of daily operation and management activities, and further enhance the core competitiveness of the enterprise market.

\section{The concept of enterprise cost management in lean accounting system}

Lean accounting system is based on the value stream management model, which effectively reduces the probability of non-value-added cost or waste cost in the daily operation and management activities of enterprises. The lean accounting system covers the relevant management contents such as just-in-time production mechanism, target cost method, value stream management mode and characteristic cost method. By means of the management contents of lean accounting system, the original cost management methods of enterprises are comprehensively optimized and upgraded. On this basis, an effective cost management framework is established for enterprises to enhance the cost of value stream. Value creation ability of management mode. 


\section{Current problems in cost management methods of enterprises}

Cost management is the core part of the enterprise management system. The level of cost determines the level of profit of the enterprise itself, and plays a key role in the survival and development of the enterprise. Although enterprises have made remarkable achievements in cost management in recent years, there are still many problems in enterprise cost management under traditional accounting, mainly in the following five aspects. As shown in Figure 1.

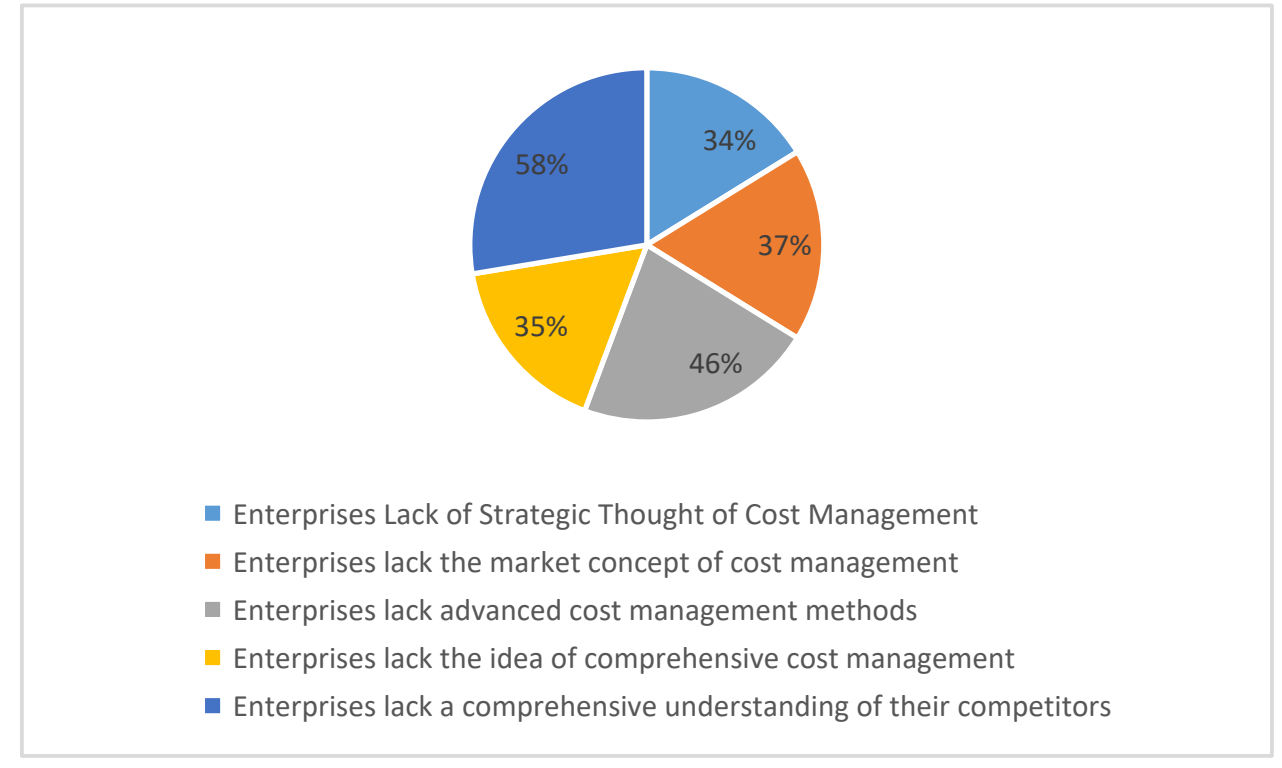

Figure 1. Current problems in cost management methods of enterprises

\subsection{Enterprises Lack of Strategic Thought of Cost Management}

Like business strategy, cost management strategy is a kind of long-term planning, focusing on cost and expense. It has four characteristics: long-term, overall, programmatic and resistant. The main purpose of cost management in practice is to take all measures to eliminate waste and reduce costs. But nowadays, the cost management strategy of enterprises lacks high degree, and can not really dig into the internal and external environment of enterprises to dig out the meaning of cost-benefit, which makes it difficult for enterprises to innovate in logistics technology and resource allocation, and to obtain long-term competitive advantages of enterprises.

\subsection{Enterprises Lack the Market Concept of Cost Management}

The lack of market concept in enterprise cost management is mainly manifested in the misunderstanding of cost management methods, means, extent and objectives. Cost is the input-output ratio of an enterprise, which is the comprehensive performance of its operation effect. Lower cost means that enterprises invest less resources to obtain more products and services, which means that the operation efficiency of enterprises is high.

\subsection{Enterprises Lack Advanced Cost Management Methods}

Enterprise cost management has three functions: providing financial reporting purpose regularly, measuring the sales cost and inventory value of products; estimating and forecasting the cost of cost objects (activities and products); improving the efficiency of enterprise operation, providing comprehensive economic information for enterprise strategic decision-making and giving feedback. 
If cost management is to give full play to the above three functions, enterprise cost information must meet the requirements of comprehensiveness, timeliness and accuracy. But at present, the enterprise cost management is still difficult to meet the above requirements, because at this stage, the enterprise cost management methods and means are still in the manual operation stage.

\subsection{Enterprises Lack the Idea of Comprehensive Cost Management}

At present, enterprise cost management pays more attention to cost management in production process, explicit cost management in material and cost management in financial accounting information, while neglecting cost management in supply process, sales process and factor organization in production process, hidden cost management in human and other aspects and cost management in non-financial accounting information.

\subsection{Enterprises Lack a Comprehensive Understanding of Their Competitors}

Enterprise cost management concept should be based on the seller's market in order to effectively carry out. The current cost concept of enterprises is more emphasis on reducing costs and improving production efficiency to meet market demand. However, this point alone ignores the overall understanding of competitors, knowing the other side can win a hundred battles. If enterprises want to survive and develop in the fierce market competition environment, they need to know their own and competitor situation, and use advanced computer simulation to predict competitors' cost indicators, find out the cost differences with competitors, learn from each bother's strengths and make up for each bother's weaknesses, so as to continuously improve the competitiveness of enterprises in the market environment.

\section{Specific Measures of Enterprise Cost Management in Lean Accounting System}

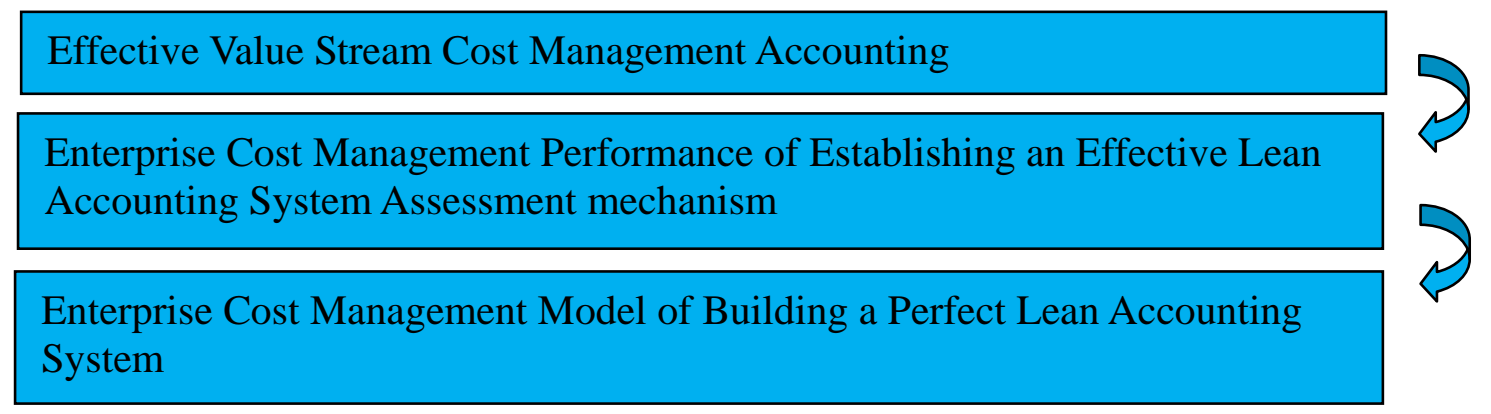

Figure2. Specific Measures of Enterprise Cost Management in Lean Accounting System

Detailed analysis will be carried out below as shown in Figure 2.

\subsection{Effective Value Stream Cost Management Accounting}

Enterprise cost management under lean accounting system helps staff of enterprise cost management to intuitively grasp the whole process of cost calculation arising from the actual operation and management activities of enterprises by using value stream cost management accounting mode, which makes the cost financial information of enterprises more transparent and specific, and enables all employees of enterprises to clearly understand each cost. The use of expenses invisibly penetrates the concept of cost management into the hearts of all employees of enterprises, thus establishing a nationwide cost management supervision mechanism. In addition, the cost management mode of value stream is the core of lean accounting. By carrying out the cost 
management of value stream, it effectively simplifies the calculation process of cost generated by the actual operation and management activities of enterprises, reduces the attention of the intermediate tracking link, and enables the staff of enterprise cost management to focus more on cost management as well as cost management. Cost control work.

Based on this, the staff of enterprise cost management should reasonably distribute the cost of actual operation and management activities to account for enterprise cost. Management provides data support. In order to ensure the accuracy between the cost and value flow generated by the actual operation and management activities, the staff of enterprise cost management should monitor the cost and cost expenditure and quantity of the waste or reworked products produced by the enterprise in real time, so that the quantity of the waste or reworked products produced by the enterprise can be controlled within the scope of the value flow and avoided. Avoid overstocking of goods due to overcapacity.

\subsection{Enterprise Cost Management Performance of Establishing an Effective Lean Accounting System Assessment mechanism}

Establishing an Effective Lean Accounting System for Enterprise Cost Management Performance Assessment Mechanisms to help staff in cost management to bring non-conformity to the enterprise Elimination of Cost and Expenditure from Practical Operation and Management Activities of Assessment Standards. In addition, the enterprise cost management should be formulated to meet the actual business management needs of the enterprise.Manage performance appraisal criteria. Take the production equipment of enterprises as an example, enterprise cost management The staff inspected the efficiency and frequency of production equipment in all aspects.And the related reports of product inspection to establish effective enterprise cost management Management of performance evaluation standards, in order to make the enterprise cost management performance evaluation Nuclear standards can meet the accounting needs of enterprise cost management in lean accounting system. The staff of enterprise cost management can take the hour as the life of the enterprise.Performance evaluation criteria for cost management of production equipment shall be set at regular intervals.Cost Cost and Value Flow of Exhibition Production Equipment in Use Matching work between workshops, and thus on the production of waste products, reworked products Real-time tracking of quantity, the first time to find the existence of enterprise production process Enterprise Cost Management in Lean Accounting System and Combining with Enterprise Practice Business management activities to develop operable solutions, timely scheduling Eliminate the hidden trouble of enterprise cost management in lean accounting system.

\subsection{Enterprise Cost Management Model of Building a Perfect Lean Accounting System}

Perfect enterprise cost management mode of lean accounting system needs to work from two aspects. The first is to strengthen the level of financial information quality of enterprises. On the one hand, in order to effectively strengthen the level of financial information quality of enterprises, enterprises should strengthen the training of financial management staff so as to standardize the work of enterprise financial management. The development mechanism enables the staff of enterprise financial management to cooperate effectively with the staff of enterprise cost management so as to improve the accuracy between the cost and economic benefits of the actual operation and management activities of the enterprise.

On the other hand, enterprise staff should try to carry out the cost management of lean accounting system from the aspect of enterprise actual operation and management cost decision-making. For this reason, the staff of enterprise cost management should strengthen the 
inventory cost management of JIT to make inventory and enterprise economic efficiency.

\section{Conclusion}

To sum up, it is necessary for managers of enterprises to strengthen the research and analysis of enterprise cost management based on accounting system, to fully understand the concept of enterprise cost management in accounting system, and to further establish a correct understanding of the accounting system. Based on this, the managers of enterprises need to start with the cost management accounting of value stream, the establishment of an effective accounting system and the performance evaluation mechanism of cost management, so as to construct a perfect enterprise cost management model of lean accounting system, thoroughly get rid of the interference of the old cost management model on the operation and management activities of enterprises, so as to ensure the quality of products. Effectively expand the operating efficiency of enterprises.

\section{References}

[1] Pan ski. Research on J-E-Commerce Enterprise Cost Management System Based on Lean Accounting [D]. Harbin Commercial University, 2017.

[2] Wang Tongue. Research on Enterprise Cost Management Based on Lean Accounting System --- Take Tianjin Jinni Group Liquor Production Value Stream as an example [J]. Monthly Journal of Finance and Accounting, 2015.

[3] Inhuman. Analysis of Enterprise Cost Management Measures in Lean Accounting System [J]. Knowledge Economy, 2015.

[4] Jingo Wei. Research on Enterprise Cost Management Based on Lean Accounting System [D]. Tianjin University of Technology, 2015.

[5] Yang Bu. On Innovative Measures of Enterprise Cost Management System under Lean Accounting System [J]. New Economy, 2014 